\title{
DAMPAK KEBERADAAN MINIMARKET TERHADAP WARUNG KECIL DI KABUPATEN KARAWANG
}

\author{
Santi Pertiwi Hari Sandi \\ Mumun Maemunah \\ 1)Santi.pertiwi@ubpkarawang.ac.id 2)Mumun.maemunah@ubpkarawang.ac.id \\ Universitas Buana Perjuangan Karawang Jl. HS.Ronggo Waluyo, Timur, \\ Karawang, Jawa Barat 41361
}

\begin{abstract}
Ringkasan
Penelitian ini bertujuan untuk (1) mengetahui kebijakan yang berkaitan dengan minimarket dan warung kecil di Kabupaten Karawang, (2) mengetahui dampak keberadaan minimarket terhadap warung kecil di Kabupaten Karawang, (3) mengetahui upaya pemerintah dalam menjalankan Peraturan Bupati Karawang Nomor 75 Tahun 2012 tentang perubahan kedua atas peraturan bupati karawang nomor 4 tahun 2010 tentang pedoman penataan dan pembinaan pasar tradisional, pusat perbelanjaan dan toko modern (mini market), (4) mengetahui upaya yang dilakukan warung kecil untuk mempertahankan eksistensi usahanya.

Penelitian ini dilakukan dengan subyek pedagang pada warung kecil di Kabupaten Karawang. Penelitian ini termasuk penelitian deskriptif kualitatif. Variabel dalam penelitian ini adalah keberadaan minimarket dan warung kecil. Populasi dalam penelitian ini adalah pedagang warung kecil dan konsumen warung kecil yang merasakan keberadaan minimarket di Kabupaten Karawang. Teknik pengumpulan data menggunakan angket, wawancara, dan dokumentasi.

Hasil penelitian menunjukkan bahwa (1) Kebijakan Peraturan Bupati Karawang Nomor 75 Tahun 2012 tentang perubahan kedua atas peraturan Bupati Karawang nomor 4 tahun 2010 tentang pedoman penataan dan pembinaan pasar tradisional, pusat perbelanjaan dan toko modern (mini market). (2) Dampak adanya minimarket dalam hal ini yaitu alfamart dan indomaret terhadap warung kecil terutama dari omset dan pendapatan yang mengalami penurunan sebanyak $77,2 \%$, jumlah konsumen yang berkunjung ke warung kecil menurun terutama pada masa akhir bulan (gajian) yaitu sejumlah 23\%, Pelayanan yang diberikan pedagang warung kecil berbeda dengan di minimarket dan jenis barang yang diinginkan oleh konsumen, (3) Upaya yang dilakukan Pemerintah dalam menjalankan Nomor 75 Tahun 2012 tentang perubahan kedua atas peraturan Bupati Karawang nomor 4 tahun 2010 tentang pedoman penataan dan pembinaan pasar tradisional, pusat perbelanjaan dan toko modern (mini market) masih minim, (4) upaya yang dilakukan dalam mempertahankan eksistensi warung kecil masih kurang.
\end{abstract}


Keywords : Pengaruh, Minimarket, Warung Kecil

\section{PENDAHULUAN}

Persaingan warung kecil dengan minimarket merupakan fenomena yang tidak asing lagi bagi kita, terutama pada zaman era globalisasi dan perkembangan ilmu pengetahuan yang semakin pesat. Penyebab terjadinya persaingan antara keduanya adalah karena keduanya memiliki kesamaan dalam menjual produk kebutuhan sehari-hari, hanya model pelayanan dan fasilitas yang berbeda. Indonesia menjadi rumah bagi bisnis minimarket di Asia Tenggara. Laporan Nielsen's What's Next for Southeast Asia menunjukkan, jumlah minimarket di Indonesia mencapai 43.826 toko pada 2017. Dari tahun ke tahun, pertumbuhan ini meningkat sekitar 3,2\%, jumlah minimarket mencapai lebih dari 40 ribu dengan pertambahan lebih dari 1.000 minimarket setiap tahun (www. marketeers.com, 2019). Apabila hal ini terus terjadi, maka tidak menutup kemungkinan bahwa warung-warung kecil akan punah.

Kabupaten Karawang merupakan salah satu yang memiliki aturan mengenai penempatan toko modern ini sebagaimana dituangkan dalam Peraturan Bupati Karawang Nomor 75 Tahun 2012 tentang perubahan kedua atas Peraturan Bupati Karawang Nomor 4 tahun 2010 tentang pedoman penataan dan pembinaan pasar tradisional, pusat perbelanjaan dan toko modern. Dilansir dari dataroom.karawangkab.go.id, dalam pasal 10 huruf b disebutkan bahwa usaha toko modern yang luas lantainya di atas $200 \mathrm{~m} 2$ sampai dengan 1.000 $\mathrm{m} 2$ harus berjarak radius sekurang-kurangnya $1,0 \mathrm{~km}$ dari pasar tradisional/desa dan terletak di sisi jalan Kolektor/Arteri dan atau merupakan jalur perniagaan. Dalam peraturan bupati tersebut sudah menyebutkan bahwa pendirian minimarket seharusnya juga memperhatikan keberadaan warung atau toko di wilayah sekitar yang lebih kecil dibandingkan dengan minimarket tersebut, namun saat ini yang dilihat bahwa keberadaan minimarket banyak yang berdiri dekat dengan warung kecil yang lebih kecil dibandingkan minimarket yang menyebabkan kekhawatiran pemilik usaha warung kecil atas kelangsungan usahanya.

Penelitian-penelitian yang terkait mengenai dampak keberadaan minimarket terhadap warung kecil sudah cukup banyak dilakukan. Penelitian yang dilakukan oleh Selpi Yana Br. Ginting (2018) dalam penelitiannya keberadaan mini market alfamart dan indomaret kaitannya dengan tingkat penghasilan pedagang tradisional di wilayah Kecamatan Talang Kelapa Kabupaten Banyuasin Sumatera Selatan. Hasil penelitian menunjukkan bahwa keberadaan minimarket, alfamart, dan indomaret berpengaruh nyata terhadap tingkat penghasilan pedagang tradisional di wilayah Talang Kelapa Sumatera Selatan. Dampak yang paling dirasakan pedagang tradisional adalah penurunannya omset yang signifikan, dengan range penurunan omset antara 25\%-60\%. Sebagian besar mengakui penurunan omset disebabkan karena konsumen saat ini lebih memilih berbelanja ke Alfamart maupun Indomaret yang memang lebih lengkap sehingga lebih menarik konsumen untuk berbelanja. Mujahid dan Nasyirah Nurdin (2018) dalam penelitiannya dampak keberadaan minimarket terhadap warung kecil di Kota Makassar. Hasil penelitian mengetahui bahwa dengan 
hadirnya minimarket memberikan dampak kepada warung kecil.

Berdasarkan penelitian-penelitian di atas maka dapat dibuat sintesa, bahwa dampak keberadaan minimarket terhadap warung kecil mempunyai dampak negatif dan sangat jelas mempengaruhi pendapatan, omzet, jumlah pelanggan pada warung kecil. Tetapi dibalik dampak negatif yang terjadi pada warung kecil dengan munculnya minimarket sendiri menjadi dampak positif untuk mengurangi jumlah pengangguran dengan membuka kesempatan kerja. Oleh karena itu, penelitian ini bertujuan untuk mengetahui dampak keberadaan minimarket terhadap warung kecil di Kabupaten Karawang. Berdasarkan hal di atas, maka peneliti mengambil judul penelitian yaitu "Dampak Keberadaan Minimarket terhadap Warung Kecil di Kabupaten Karawang”.

\section{Perumusan Masalah}

Berdasarkan pada latar belakang yang terurai diatas maka dapat dirumuskan masalah yang akan diteliti pada penelitian ini adalah sebagai berikut:

1. Bagaimana kebijakan yang berkaitan dengan minimarket dan warung kecil di Kabupaten Karawang?

2. Bagaimana dampak dari keberadaan minimarket terhadap warung kecil di Kabupaten Karawang?

3. Bagaimana upaya pemerintah dalam menjalankan Peraturan Bupati Karawang Nomor 75 Tahun 2012 tentang perubahan kedua atas peraturan bupati karawang nomor 4 tahun 2010 tentang pedoman penataan dan pembinaan pasar tradisional, pusat perbelanjaan dan toko modern (mini market)?

4. Bagaimana upaya yang dilakukan warung kecil untuk mempertahankan eksistensi usahanya?

\section{Tujuan Penelitian}

Berdasarkan pada rumusan masalah yang terurai diatas maka dapat dibentuk tujuan pada ini adalah sebagai berikut:

1. Untuk mengetahui kebijakan yang berkaitan dengan minimarket dan warung kecil di Kabupaten Karawang?

2. Untuk mengetahui dampak dari keberadaan minimarket terhadap warung kecil di Kabupaten Karawang.

3. Untuk mengetahui upaya pemerintah dalam menjalankan Peraturan Bupati Karawang Nomor 75 Tahun 2012 tentang perubahan kedua atas peraturan bupati karawang nomor 4 tahun 2010 tentang pedoman penataan dan pembinaan pasar tradisional, pusat perbelanjaan dan toko modern.

4. Untuk mengetahui upaya yang dilakukan warung kecil untuk mempertahankan eksistensi usahanya. 


\section{Tinjauan Pustaka}

\section{Pengertian Dampak}

Pengertian dampak menurut Kamus Besar Bahasa Indonesia adalah benturan, pengaruh kuat yang mendatangkan akibat baik positif maupun negatif (KBBI Online,2019). Dampak secara sederhana bisa diartikan sebagai pengaruh atau akibat. Dalam setiap keputusan yang diambil oleh seseorang atau diri sendiri pun biasanya mempunyai dampak tersendiri, baik itu dampak positif maupun dampak negatif.

\section{Pengertian Sosial}

Kata sosial berasal dari kata "Socius" yang artinya kawan (teman), dalam hal ini arti kawan bukan terbatas sebagai teman sepermainan, teman kelas, teman sekampung dan sebagainya (Imron dan Aka, 2018:153). Pengertian sosial menurut Kamus Besar Bahasa Indonesia adalah berkenaan dengan masyarakat, suka memperhatikan kepentingan umum (KBBI Online, 2019).

\section{Pengertian Ekonomi}

Menurut Soekanto dan Budi (2013:14) ekonomi adalah suatu hal yang bersangkutan dengan sistem produksi, distribusi, dan pengunaan barang-barang dan jasa-jasa (konsumsi). Hal-hal yang bersangkutan dengan sistem ekonomi ini adalah permasalahan yang dikaji dalam ilmu-ilmu sosial pada kehidupan masyarakat. Ekonomi adalah ilmu mengenai asas-asas produksi, distribusi, dan pemakaian barangbarang serta kekayaan (seperti hal keuangan, perindustrian, dan perdagangan) (KBBI Online, 2019).

\section{Minimarket}

Peraturan Bupati Karawang Nomor 75 Tahun 2012 tentang perubahan kedua atas peraturan bupati karawang nomor 4 tahun 2010 tentang pedoman penataan dan pembinaan pasar tradisional, pusat perbelanjaan dan toko modern. Dilansir dari dataroom.karawangkab.go.id, dalam pasal 1 ayat 17 minimarket adalah sarana/ tempat usaha untuk melakukan penjualan barang-barang kebutuhan sehari-hari secara eceran dan langsung kepada konsumen akhir dengan cara swalayan yang luas lantai usahanya paling besar (maksimal) $400 \mathrm{~m}^{2}$. Berdasarkan teori-teori diatas, sintesa dari minimarket adalah salah satu tempat untuk berbelanja yang cukup luas, nyaman dan jaraknya pun tidak terlalu dari pemukiman warga. Minimarket dalam Peraturan Perundang-undangan termasuk dalam pengertian "Toko Modern". Peraturan mengenai toko modern diatur dalam Peraturan Presiden Nomor 112 Tahun 2007 Tentang Penataan dan Pembinaan Pasar Tradisional, Pusat Perbelanjaan, dan Toko Modern. Pengertian toko modern menurut Pasal 1 Angka 5 Peraturan Presiden Nomor112 Tahun 2007 Tentang Penataan dan Pembinaan Pasar Tradisional, Pusat Perbelanjaan, dan Toko Modern adalah toko dengan sistem pelayanan mandiri, menjual berbagai jenis barang secara eceran yang berbentuk Minimarket, 
Supermarket, Department Store, Hypermarket ataupun grosir yang berbentuk perkulakan.

\section{Warung Kecil}

Warung kecil atau yang biasa disebut dengan toko kelontong merupakan penyedia kebutuhan sehari-hari merupakan usaha mikro yang kepemilikannya dimiliki oleh pribadi dan melakukan penjualan barang yang bersifat melayani pelanggan atau konsumen datang untuk membeli barang tidak dengan mandiri, yaitu dengan dilayani langsung oleh pelayan toko kelontong tersebut, dan pada umumnya pada toko kelontong yang skala kecil pelayan toko merangkap sebagai kasir juga. Jadi, toko kelontong dapat dikatakan sebagai usaha mikro disesuaikan dengan pengertian menurut UU No. 20 Tahun 2008, usaha mikro adalah usaha ekonomi produktif yang berdiri sendiri, yang dilakukan oleh perorangan atau badan usaha yang bukan merupakan anak perusahaan atau bukan cabang perusahaan yang dimiliki, dikuasai, atau menjadi bagian baik langsung maupun tidak langsung dari usaha menengah atau usaha besar yang memenuhi kriteria Usaha Kecil sebagaimana dimaksud dalam Undang-Undang.

\section{Kerangka Pemikiran}

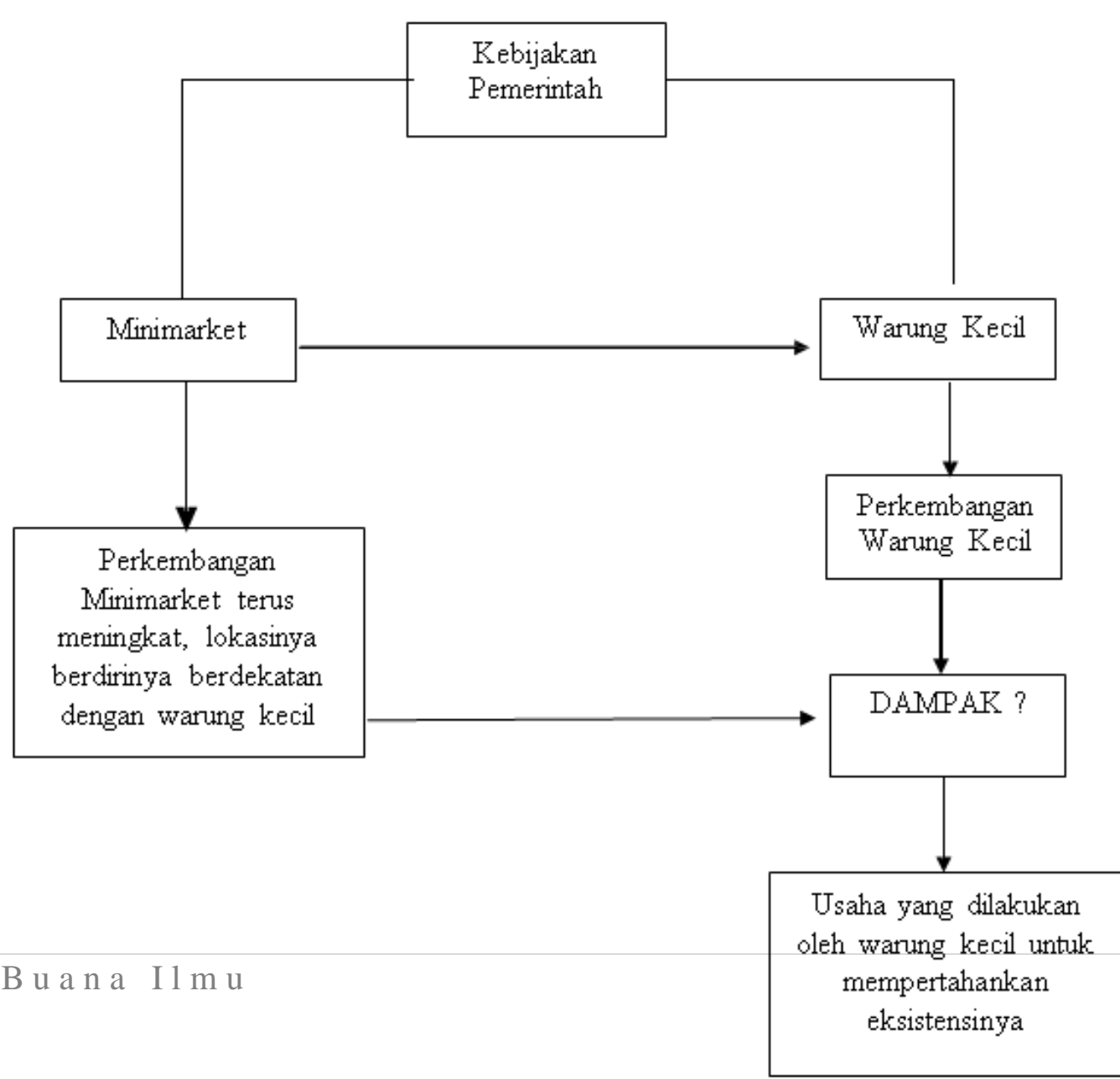




\author{
Gambar 2.1 \\ Kerangka Pemikiran \\ Sumber : Kajian Peneliti, 2019
}

\title{
Metode Penelitian
}

Penelitian ini menggunakan metode pendekatan deskriptif kualitatif.

\section{Hasil dan Pembahasan}

Kebijakan yang berkaitan dengan pasar modern dan pasar tradisional yaitu Peraturan Presiden Republik Indonesia Nomor 112 Tahun 2007. Peraturan Presiden Republik Indonesia Nomor 112 Tahun 2007 memuat pasal-pasal tentang pasar tradisional, yaitu: Pendirian pusat perbelanjaan dan toko modern wajib memperhatikan jarak antara hypermarket dengan pasar tradisional yang telah ada sebelumnya ( pasal 4 ayat 1 poin b. Peraturan Presiden Republik Indonesia Nomor 112 Tahun 2007). Dalam kenyataannya, pendirian toko modern di Kabupaten Karawang tidak mengacu pada pasal tersebut. Terdapat minimarket dengan jarak $180 \mathrm{~m}$ (seratus delapan puluh meter) dari lokasi pasar Kosambi untuk kecamatan Klari, dan banyak warungwarung eceran berada disekitar minimarket tersebut, berjarak $50 \mathrm{~m}$ (lima puluh meter) dan ada yang berhadapan langsung dan bersampingan langsung dengan minimarket.

Dampak adanya minimarket terhadap warung kecil dilihat dari segi omset. Dari 70 responden, yang mengalami penurunan omset sebesar 54 responden atau sebesar 77,2\%. Dan terdapat $16(22,8 \%)$ responden yang mengatakan bahwa omset mereka tidak berubah atau netral. Dilihat dari segi pendapatan, rata-rata pendapatan pedagang pasar tradisional sebelum adanya pasar modern sebesar Rp 1.123.571,00/hari turun menjadi Rp 781.857,00/hari setelah adanya minimarket. Dilihat dari segi Jumlah pelanggan, mereka mengalami penurunan yang cukup besar. Jumlah pelanggan mereka dari rata-rata 46 konsumen per hari menjadi 28 konsumen perhari atau mengalami penurunan sebanyak 17 konsumen atau sekitar 34,68\%. Jumlah pelanggan mereka dari rata-rata 44 konsumen per hari menjadi 32 konsumen perhari atau mengalami penurunan sebanyak 11 konsumen atau sekitar $23 \%$.

Upaya yang dilakukan Pemerintah dalam menjalankan Peraturan Bupati Karawang Nomor 75 Tahun 2012 tentang perubahan kedua atas peraturan bupati karawang nomor 4 
tahun 2010 tentang pedoman penataan dan pembinaan pasar tradisional, pusat perbelanjaan dan toko modern (mini market) masih minim.

Upaya yang dilakukan Pemerintah dalam menjalankan Peraturan Daerah Nomor 20 Tahun 2016 masih minim. Mengenai Upaya untuk eksistensi warung kecil terhadap keberadaan minimarket masih kurang.

\section{Kesimpulan}

Kebijakan yang berkaitan dengan pasar modern dan pasar tradisional yaitu Peraturan Presiden Republik Indonesia Nomor 112 Tahun 2007. Peraturan Presiden Republik Indonesia Nomor 112 Tahun 2007 memuat pasal-pasal tentang pasar tradisional, yaitu: Pendirian pusat perbelanjaan dan toko modern wajib memperhatikan jarak antara hypermarket dengan pasar tradisional yang telah ada sebelumnya ( pasal 4 ayat 1 poin b. Peraturan Presiden Republik Indonesia Nomor 112 Tahun 2007). Dalam kenyataannya, pendirian toko modern di Kabupaten Karawang tidak mengacu pada pasal tersebut.

Dampak adanya minimarket terhadap warung kecil mengalami penurunan omset, penurunan pendapatan dan penurunan jumlah pelanggan.

Upaya yang dilakukan Pemerintah dalam menjalankan Peraturan Bupati Karawang Nomor 75 Tahun 2012 tentang perubahan kedua atas peraturan bupati karawang nomor 4 tahun 2010 tentang pedoman penataan dan pembinaan pasar tradisional, pusat perbelanjaan dan toko modern (mini market) masih minim.

Upaya yang dilakukan Pemerintah dalam menjalankan Peraturan Daerah Nomor 20 Tahun 2016 masih minim. Mengenai Upaya untuk eksistensi warung kecil terhadap keberadaan minimarket masih kurang.

\section{Saran}

Kebijakan yang berkaitan dengan pasar modern dan pasar tradisional yaitu Peraturan Presiden Republik Indonesia Nomor 112 Tahun 2007. Sebaiknya pemerintah sebelum memberikan izin akan didirikan usaha tersebut meninjau kembali lokasi yang akan didirikan, karena masih banyak minimarket-minimarket yang berlokasi kurang dari 500m (lima ratus meter) dari pasar tradisional dan warung kecil.

Dampak adanya minimarket terhadap warung kecil sudah terlihat jelas, sebaiknya pemerintah daerah juga memperhatikan manajemen pasar yang baik, agar warung kecil pun bisa terintegrasi dengan baik dan bisa bersaing dengan minimarket yang sudah banyak sekali.

Upaya yang dilakukan Pemerintah Daerah harus selalu ditingkatkan dan harus bisa mengambil keputusan yang bijak terhadap kelangsungan para pedagang warung kecil dan minimarket. 
Sebaiknya dilakukan upaya untuk meningkatkan eksistensi, misalnya memperbaiki fasilitas, kualitas pelayanan, kerapihan dan memberikan discount untuk pembelanjaan pada jumlah tertentu agar menarik konsumen.

\section{DAFTAR PUSTAKA}

\section{Buku dan Jurnal \\ Buku:}

Damsar dan Indrayani. 2016. Pengantar Sosiologi Perdesaan Edisi Pertama. Jakarta: Kencana.

Imron, Ilmawati Fahmi. 2018. Fenomena Sosial. Banyuwangi: LPPM Institut Islam Ibrahimy Genteng Banyuwangi.

Kuncoro, Mudrajad. 2009. Ekonomika Indonesia : Dinamika Lingkungan Bisnis di Tengah Krisis Global. Yogyakarta : UPP STIM YKPN.

Madya, S. 2009. Teori dan Praktik Penelitian Tindakan:Action Research. Bandung: Alfabeta.

Raco. 2010. Metode Penelitian Kualitatif. Jakarta: Grasindo.

Salim, A. 2002. Perubahan Sosial: Sketsa Teori dan Refleksi Metodologi Kasus Indonesia. Yogyakarta: Tiara Wacana.

Soekanto, Soerjono dan Budi Sulistyowati. 2013. Sosiologi Suatu Pengantar. Depok: PT. Raja Grafindo Persada.

Sugiyono. 2009. Metode Penelitian Kuantitatif, Kualitatif dan R\&D. Bandung: Alfabeta.

Sugiyono. 2011. Penelitian Kualitatif. Jakarta: Kencana Prenada Media Grup. Sujana, Asep ST. 2012. Manajemen Minimarket. Jakarta: Raih Asa Sukses.

Wagiran. 2013. Metodologi Penelitian Pendidikan Teori dan Implemtasi. Yogyakarta: CV Budi Utama.

Zamron, M. 2009. Buku Kantong Ekonomi IPS. Yogyakarta: Pustaka Widyatama.

\section{Jurnal:}

Selpi Yana Br. Ginting. 2018. "Keberadaan Minimarket Alfamart dan Indomaret kaitannya dengan Tingkat Penghasilan Pedagang Tradisional di Wilayah Kecamatan Talang Kelapa Kabupaten Banyuasin Sumatera Selatan”. Jurnal Swarnabhumi Vol.3, No. 1, Agustus 2018.

Wita Dwika Listihana, Afvan Aquino \& Arizal. 2014. "Dampak Keberadaan Minimarket Terhadap Modal Kerja dan Pendapatan Warung Tradisional di Kecamatan Rumbai dan Rumbai pesisir Kota Pekanbaru". Jurnal Ilmiah Ekonomi dan Bisnis Vol 11, No. 1, Maret 2014. 
Mujahid dan Nasyirah Nurdin. 2018. "Dampak Keberadaan Minimarket Terhadap Warung Kecil Di Kota Makassar”. Jurnal Sinar Manajemen Vol 5, No. 1, 2018.

Rina Walmiaty Mardi. 2017. "Dampak Munculnya Minimarket Waralaba Terhadap Usaha Kecil Pada Kecamatan Medan Tuntungan Sumatera Utara”. Vol 1, 16 Desember 2017.

Jaziela Muslihatunnisa (2015). Dampak keberadaan minimarket franchise terhadap usaha pedagang kelontong di Kecamatan pacitan Jawa Timur. Jurnal online perpustakaan UGM. http://etd.repository.ugm.ac.id/penelitian/detail/82805

Rina Arnisyah. 2020. Analisis Dampak Keberadaan Minimarket Terhadap Kelangsungan Usaha Toko Kelontong (Studi Kasus Di Wilayah Kelurahan Srengseng, Kecamatan Kembangan, Jakarta Barat). http://repository.uinjkt.ac.id/

Zumrotul Muhzinat, Siti Achiria. 2019. Dampak Keberadaan Minimarket terhadap Toko Kelontong diPasar Klampis Kabupaten Bangkalan Madura

Yossi Hardian aditya Purwa. 2018. Pengaruh Minimarket Terhadap Pendapatan Pedagang Pasar Tradisional. (Studi Kasus Pasar Cerme Kecamatan Baturraden Kabupaten Banyumas)

Nashiruddin. 2012. Dampak keberadaan indomaret terhadap pendapatan pedagang kelontong di pasar cuplik kecamatan sukoharjo. eprints.ums.ac.id/20414/9/11._NASKAH_PUBLIKASI.pdf

\section{Peraturan, Kebijakan dan Buku Pedoman}

1. Undang-Undang Republik Indonesia Nomor 20 Tahun 2008 Pasal 1 Ayat 2 usaha kecil adalah usaha ekonomi produktif.

2. Peraturan Bupati Karawang Nomor 75 Tahun 2012 tentang perubahan kedua atas Peraturan Bupati Karawang Nomor 4 Tahun 2010 tentang pedoman penataan dan pembinaan pasar tradisional, pusat perbelanjaan dan toko modern.

3. Perpres No. 112 Tahun 2007 dan Permendagri No. 53 Tahun 2008 yang mengatur tentang penataan dan pembinaan pasar tradisional, pusat perbelanjaan dan toko modern

4. Undang-Undang Republik Indonesia Nomor 20 Tahun 2008 Tentang Usaha Mikro, Kecil, dan Menengah

5. Permendag 53/2008 Pasal 3 ayat (9) Pedoman Penataan dan Pembinaan Pasar Tradisional, Pusat Perbelanjaan dan Toko Modern 
Santi Pertiwi Hari Sandi, Mumun Maemunah

Vol 5 No 1

ISSN : 2541-6995

E ISSN : 2580-5517

6. Peraturan Menteri Perdagangan Nomor 70/M-3DAG/PER/12/2013 Tentang Pedoman Penataan dan Pembinaan Pasar Tradisional, Pusat Perbelanjaan, dan Toko Modern

\section{III.Situs Website:}

https://id.wikipedia.org/wiki/Warung. Diakses tanggal 14 Agustus 2019.

https://marketeers.com/jumlah-minimarket-indonesia-terbanyak-di-asia-tenggara/.

Diakses tanggal 14 Agustus 2019.

https://karawangkab.bps.go.id/. Diakses tanggal 14 Agustus 2019. https://kbbi.web.id/.

Diakses tanggal 15 Agustus 2019.

https://radarkarawang.id/metropolis/selama-2018-izin minimarket-60-unit/Selama 2018 Izin

Minimarket 60 Unit. Diakses 14 Agustus 2019

www.karawangkab.bps.go.id (2019)

www.google.com/https://kbbi.web.id/dampak (diakses 14 Agustus 2019 pukul 16.23 WIB). 